Jakub Galuszka

\title{
Beyond the decay? Positive patterns in the development of a large housing estate: the case of Olechów-Janów district in Łódź, Poland
}

Journal article | Accepted manuscript (Postprint)

This version is available at https://doi.org/10.14279/depositonce-10513

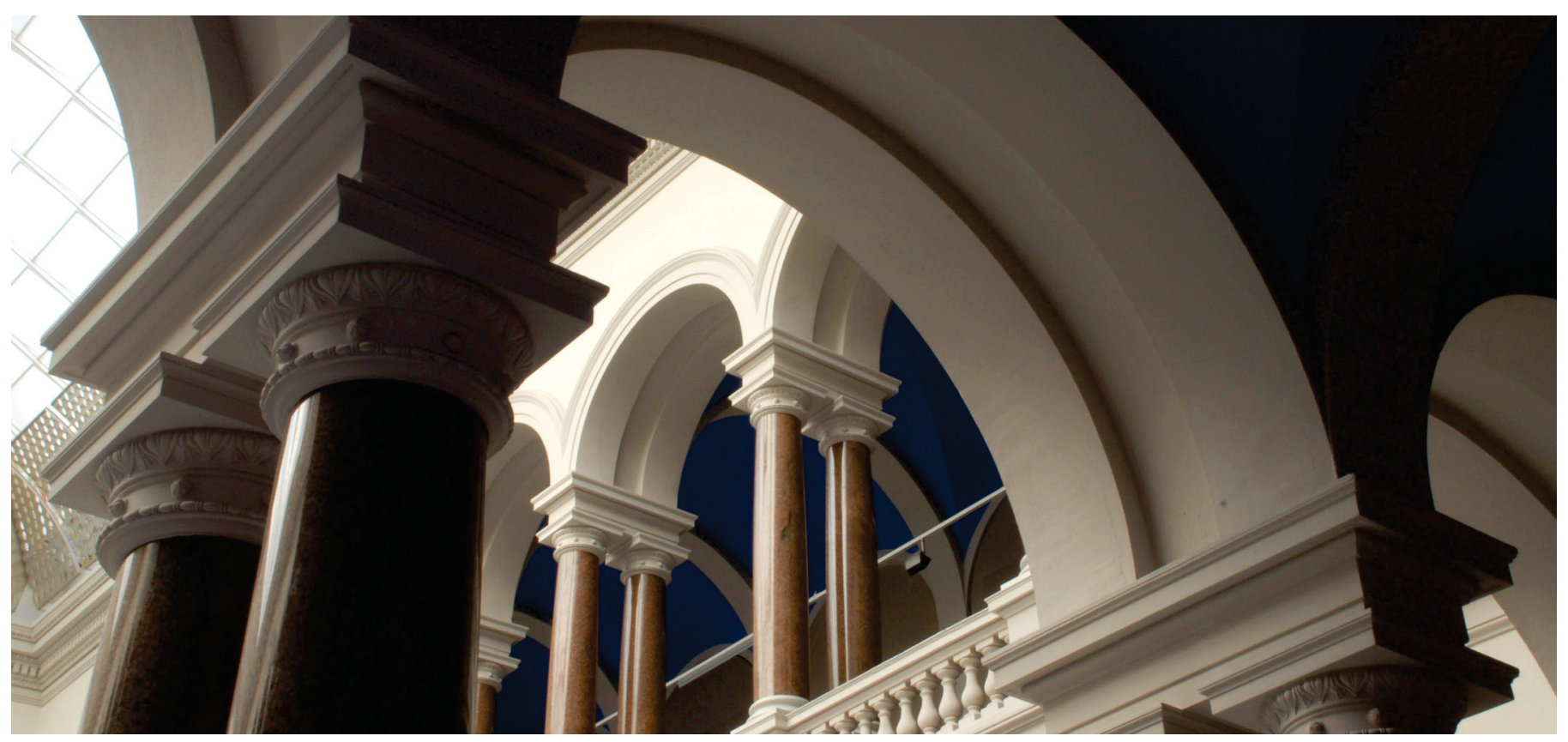

This is an Accepted Manuscript of an article published by Taylor \& Francis in Urban Research \& Practice on 03 Jul 2020, available online: http://www.tandfonline.com/10.1080/17535069.2020.1782459

Galuszka, J. (2020). Beyond the decay? Positive patterns in the development of a large housing estate: the case of Olechów-Janów district in Łódź, Poland. Urban Research \& Practice, 1-25.

https://doi.org/10.1080/17535069.2020.1782459 


\title{
Beyond the decay? Positive patterns in the development of a large housing estate: the case of Olechów-Janów district in Łódź, Poland
}

\begin{abstract}
A lot of attention in the academic and policy debate has been given to the process of transformation of large housing estates in Central and Eastern Europe post 1989. This included debate about their decreasing socio-economic status and the gradual deterioration of housing structures. Nevertheless the transformation processes in various estates have not necessarily followed the same pattern and some districts, instead of decaying, have continued to grow during the capitalist period. This article discusses the case of one such estate in the city of Łódź in Poland, documents the 'alternative' format of transformation and discusses its implications for policy making.
\end{abstract}

\section{Introduction}

During the second half of the 20th century, large housing estates emerged as a dominant housing modality in socialist countries in Central and Eastern Europe (CEE). These state-subsidised structures were composed of groups of apartment buildings typically created as a single development, with a distinct form and carried out in a large scale for a local context. They involved interventions planned at a neighbourhood, building and apartment levels, with an intention to provide middle and working class families with quality environment in a cost-effective way (Hess, Tammaru and van Ham 2018). As such, the large housing estates were treated by the authorities as a remedy for housing shortages but also as an ideological project for building a new, egalitarian socialist society. While delivered with significant delays and contested in terms of design and quality (Eros 2013), the centrally-planned large housing estates did indeed emerge as socially diverse and densely-populated neighbourhoods which generated their own identities and distinctive ways of living (Rykiel 1999). Along with the fall of the socialist regimes in the early 1990s, the character of large housing estates was about to change. New urban trends such as the market-driven regeneration of inner cities (Temelová 2007) and the emergence of suburban, single-family housing districts contributed to the emigration of middle-class populations and their replacement with more uniform lower- 
middle-class ones (Hirt 2013), particularly in economically successful cities like Krakow or Warsaw (Marcińczak et al. 2012). This process is identified by some authors (Szeleny 1996; Czepczyński 1999; Rykiel 1999), international organisations (EU 2011) and policy makers as a serious threat to the sustainable and cohesive development of the local cities.

The ongoing homogenisation of the social profile of their inhabitants and the aging of the buildings also contributed to the stigmatisation of large housing estates as 'undesirable' urban spaces where the disappearance of state support led to a 'rapid and continuous process of deterioration of the housing stock, with adverse impacts on the quality of life in cities' (World Urban Forum IX 2018). Particularly in the context of Western and Northern European cities, some large housing estates are indeed characterised by a clustering of social problems, poverty and the deterioration of structures (Hess, Tammaru and van Ham 2018). However, such perceptions have arguably reinforced some policy responses also in contexts where large housing estates are traditionally inhabited by a greater diversity of social groups. A similar process is currently taking place in Moscow, where radical demolitions have led to around 1 million people living under threat of relocation (Inizan and Coudroy de Lille 2019).

Nevertheless, the process of transformation of large housing estates, either in Western Europe or CEE, has not universally followed the same patterns. In spite of the general persistence of the negative image of large housing estates (Dean and Hastings 2000) and the outward migration of people with a high socio-economic status, such neighbourhoods are appreciated by a large portion of their inhabitants (Dekker et al. 2011). The parallel processes of the stigmatisation of large housing estates and the renewed interest of authorities in subsidised mass housing in several CEE countries motivates the inquiry of this study. The article explores the case of large housing estate located in the district of Olechów-Janów in the city of Łódź, Poland. The district is considered to be one of the most attractive in the city and, in contrast to the majority of other large housing estates in the city, is experiencing continuous population growth and expansion. However, the relative success of the district lies also beyond those factors. In spite of a general decrease of the socio-economic status in large housing estates in major cities in the region and Łódź itself, Olechów-Janów remained sociallymixed and still includes groups with high status. Furthermore, it is cited by many outsiders as a preferred location to move to and perceived to have high quality 
amenities and living standards (Krzewińska 2010; Mularska-Kucharek and Wiktorowicz, 2012). Finally, it attracts investment into top-end housing (even to a degree, which suggests the process of a new-build gentrification occurs in the district) (Szafrańska 2012).

The research presented here explores the kinds of spatial and functional amenities, beautification measures and commercial activities that have emerged in the district and how these might contribute to its popularity. At the same time, the research takes a closer look at what kind of housing typologies have emerged in Olechów-Janów during and beyond the socialist period, which factors shaped their development and how this evolution can inform policy-making and efforts to rehabilitate decaying large housing estates in different contexts. By doing so, the article links to a broader debate on the evolution of large housing estates in Europe and CEE. It adds to the growing bulk of studies illustrating diversified patterns of change in such districts. More precisely, it documents an example of an estate with a relatively unique developmental trajectory and characterised by a number of indicators suggesting positive developmental pattern. Those elements include continuous spatial and population growth, high quality of life, maintaining social-mix, introduction of diversified housing typologies as well as attracting investment into public transportation, spaces and amenities and private commercial facilities.

\section{The transformation of large housing estates in CEE post-1990}

In the early 1990s at the turn of the political system, large housing estates were positioned as the primary housing modality across CEE and Eastern Europe. The roll-out of capitalism and privatisation, and the retreat of states from the management and construction of housing stock signalled the start of the widespread transformation of these estates. With the transition process in the region directed towards replication of a Western European development model (Frencuchova 2012; Chelcea and Druţă 2016), a number of concerns were raised regarding the future of the estates. In the main, these voices assumed that there would be an exodus of higher-socio economic groups out of large housing estates and that this would coincide with their social, economic and material decline (Szeleny 1996; Czepczyński 1999; Rykiel 1999) - a pattern that had been previously documented in the context of Western European cities, where the desire to move from a district was associated with its perceived low socio-economic 
status and image of decline (Feijten and Van Ham 2009; Clark and Coulter 2015). Overall, according to this line of thought, neighbourhood attractiveness was considered to play a crucial role in the selection of a place to live. At the same time, as suggested by Clark and Coulter (2015: 2685), 'changes in the demographic or physical fabric of areas are bound up with economic processes such as gentrification or neighbourhood decline in ways which are difficult to disentangle'. For example, the new housing available to more affluent customers, suburbanisation processes, and the rehabilitation of city centres, are considered to be key external framing factors that resulted in socio-spatial segregation in CEE (Sýkora and Bouzarovski 2012).

Overall this has proven to be true in the context of major cities in Poland (including Łódź), where the post-1989 transformation process led to the concentration lower socio-economic status groups in the large housing estates (Marcińczak et al. 2012). Similarly, a cross-country analysis of estates in Leipzig, Vilnius, Sofia and Budapest illustrates how in general inhabitants of these cites perceived large housing estates rather negatively (Kovács and Herfert 2012). However, these perceptions varied significantly, with large housing estates appreciated more by their residents than by those living outside of them.

In addition, characteristics of the estates such as types of construction, levels of renovations, energy efficiency and location play an important role in their evaluation (Kovács, Egedy and Szabó 2018). For instance, some estates in Bucharest are considered to be currently undergoing a 'minor renaissance' (Marin and Chelcea 2018), while in Sofia (Stanilov 2007) or Prague many estates preserved their social-mix and underwent expansion post-1989 as a result of developers being attracted to housing estates' provision of building plots, good transportation links to the city centre, and pre-existing technical and social infrastructure (Ouředníček, Špačková and Pospíšilová 2018).

Likewise, some vertical densification through the addition of extra flats on the top of buildings has occurred in in Prague. In contrast to self-made extensions in contexts like Tbilisi, Georgia, which were driven by the needs of individual families for expanded living spaces (Salukvadze and Golubchikov 2016), these additional flats reflected the existing demand to live in estates developed during the socialist period. Similarly, an example of successful upgrading measures is visible in Leipzig-Günau, where renewal efforts translated to increased resident satisfaction and improvement of the image of the 
district (Kovács and Herfert 2012). The differences in the perceptions towards specific estates also relate to external conditions such as shortages of housing in the market (as in Sofia), suggesting that people may appreciate this type of 'non-ideal' housing when the availability of alternative housing is limited. This finding appears to hold in the Western European context also, where stigmatised neighbourhoods may be still appreciated by those with limited residential mobility opportunities such as migrant and low-income families (Dekker et al. 2011).

Overall the analysis of the transformation of large housing estates in CEE suggests that most estates experienced some degree of decrease in the socio-status of their inhabitants. Similarly, the multitude of changes in land use, building aesthetics, and the development of retail and public spaces (Hirt 2013) resulted in a number of marked differences in the characteristics of estates compared to the socialist period, as well as to the large estates in Western Europe. Estates in CEE are today significantly more likely to be considered good places to live than in Western Europe, either because of their characteristics or due to external factors such as limited availability of alternative forms of housing. While many studies analyse perceptions of inhabitants and changes to the socio-economic composition of large housing estates, holistic analyses of spatial development patterns and changes in housing typologies and commerce are less common. This study contributes in this field and documents the case of an estate considered to be one of the most attractive residential locations in the city.

\section{Methods}

The discussion presented is based on an analysis of the spatial transformation of the district during the last 30 years conducted with the use of remote sensing images (open source databases including: Ortofotomapy, Google Maps, Retromapy), the mapping of commercial activities and public spaces as well as observations and photographic documentation carried out in June 2018. Considering the focus of the study and the large number of pre-existing quantitative studies describing perceptions, valorisation and demographic and socio-economic transformations in large housing estates in Łódź, the research predominantly employs spatial methods as an alternative tool for tracing the transformation of the district. The district was selected for study based on the pre-existing quantitative data as well as on the possession of personal 
observations and experience derived from living in one of the main large housing estates in Łódź.

The utilisation of remote sensing is discussed as particularly relevant for tracing change in built-up areas, their densities and coverage as well as the spatial and temporal patterns in urbanisation processes (Maktav, Erbek and Jürgens 2005). This approach is widely applied for monitoring urban development transformation in a variety of contexts, starting with measuring historical morphological development in cities (Lefebvre and Corpetti 2016), changes in land values (Turkstra 1998), and incremental urbanism (Kamalipour and Dovey 2018), and is also universally utilized in the planning and management of urban services and development strategies (Masser 2001).

Research mapping is similarly a useful tool in urban research, enabling a 'deeper understanding of how the city works and how it might be transformed through urban planning and design' (Dovey, Ristic and Pafka 2018: 3) and can cover a majority of urban phenomena, including: functions, built form, transport, public-private interfaces, arts, conflicts, incidents of violent crime and similar.

The combination of methods utilised in the research presented is oriented towards an understanding of the spatial transformation patterns in the district and the identification of the housing typologies, as well as public spaces and amenities, which have emerged over the last 30 years and contributed to its popularity as identified through secondary research and existing quantitative data. More specifically, the remote sensing data from open source databases contributed to the identification of the patterns of growth in the district, its morphology and urban design. This was combined with observation and photographic documentation conducted in order to identify housing typologies emerging in specific periods. Additionally, the mapping of commercial activities as well as main public spaces and amenities was realised with the intention of documenting features of the district contributing to its popularity and functional mix. In contrast to other studies listing overall numbers of services identified through official registers (Szafrańska 2016), only services visible from street level were included in the study as important factors shaping street life and aesthetics and relevant to the design quality of Olechów-Janów. Consequently, spatial distribution, type of service and location have been documented through a mapping exercise covering the whole district and conducted in spring 2018. This was supplemented with secondary 
research and a review of the housing and public space oriented investments and initiatives which contributed to the development of the Olechów-Janów estate.

\section{4. Łódź transitions and the development of large housing estates}

In 2016 Łódź was the third biggest city in Poland, with a population of 696,500 people (Statistical Office in Łódź 2017). After rapid development in the $19^{\text {th }}$ and early $20^{\text {th }}$ centuries, the city experienced relatively stable growth and expansion during the socialist era and a period of decline after the change of political system in 1989. Along with the closure of the textile industry, unemployment and radical depopulation became the major issues haunting the city. Between 1984 and 2017, Łódź lost nearly 200,000 inhabitants (Szukalski 2012; Statistical Office in Łódź 2017). While these demographic trends to date remain unchanged, stable economic growth in the new millennium, as well as the availability of EU funding, have allowed considerable investment in the city. However, most of the available resources have been utilised for the regeneration of the city centre and a number of large infrastructural projects across the city.

Large housing estates started to be constructed in Łódź soon after the Second World War. Even though the city's population had fallen to 497,000 , compared to 672,000 in the pre-war period (Szukalski 2012), a shortage of housing was one of the main issues in Łódź. Consequently, the authorities initially focused on trying to increase the city's housing stock. In accordance with the ideological orientation of the government, this translated into the development of socialist realist districts, mainly in and around the former ghetto of Bałuty and Old City (Stare Miasto). Nevertheless, due to the high costs and changes in cultural policy in the country, this housing format was soon abandoned. From the end of the 1960s cheaper blocks of flats were developed using large pre-fabricated panels, and these became the main housing typology in the country. Initially, in Łódź, these types of large housing estates were located in close proximity to the inner city (with the exception of the Teofilow estate). With the approval of the new Spatial Plan for the Development of Łódź in 1972, the new districts started to be developed along the city's east-west axis (Bald 2002). This axis had been reinforced by the introduction of a large avenue that carried public transport linking the two ends of the city. In the 1980s a number of new housing estates were also introduced on the northern and southern outskirts of the city. These developments helped to partially accommodate the stable demographic growth in Łódź, whose population reached its 
peak in 1984 with 894,000 inhabitants (Szukalski 2012). In 2013 there were 348,200 flats in the city, half of which were located in multi-storey buildings constructed using prefabricated building technology (Szafrańska 2016).

Throughout the entire socialist period the construction of large housing estates was facilitated by heavily subsidised, state-led housing cooperatives which aimed at delivering housing to 'anonymous groups of people, representing medium-level needs (mainly families with children)' (Szafrańska 2013: 122). Nevertheless the transformation of the socio-spatial structure of Łódź eventually resulted in the concentration of middle and higher socio-economic classes in many of the new housing estates (Szafrańska 2016), where living conditions were perceived to be higher than in the slowly degrading inner city (Szafrańska 2013). While this trend reversed after 1989, when higher socio-economic groups started to move out of the large housing estates on the peripheries, the socio-economic composition of these districts remained relatively mixed at the beginning of the new millennium (Marcińczak and Sagan 2011). However, the unwinding of state-led housing enterprises meant a radical decrease in the amount of housing produced in the country. Between 1988 and 2013, the number of flats in the city increased by only 35,000, equal to the increase over three years during the height of construction in the second half of 1970s (Szafrańska 2016).

Similarly to CEE countries, the slow pace of housing construction was reinforced by the retreat of the state from the delivery of subsidised housing formats and the dismantling of cooperative housing corporations. Additionally, the privatisation of housing stock and restitution processes reinforced the positioning of the private sector as the main responsible party in housing construction. These processes were linked to efforts to create a market economy and the ideological currents motivating such processes in the 1990s (Lux and Mikeszova 2012). A major shift in the local housing market was reflected in law on 28 December 1989 with a resolution to convert subsidised credits taken by housing cooperatives to their real market value. Similarly, progressive decentralisation in the country left its mark on the housing cooperatives, which were either divided into multiple organisations or dissolved (Kasicka et al. 2008). As a consequence, less than $3 \%$ of new dwellings in Poland are currently built by housing cooperatives (Coudroy de Lille 2015).

Some forms of subsidised housing were reintroduced in 1995 through the Act on Selected Forms of Support of Housing Construction (Cooperative Housing International, 2018), including rental housing development by not-for-profit Social Housing 
Companies - 'Towarzystwo Budownictwa Spolecznego' (TBS). Nevertheless, since the main responsibility for housing construction was taken over by private developers, a large bulk of the new housing on offer targeted affluent customers and took the shape of single-housing family units or gated communities taking a form of full-fledged, securitized residential environment including numerous dwellings and common services in one fenced area (Hirt, 2013).

In parallel, the city authorities started to diversify their strategic development priorities, with a specific focus on the impoverished city centre. The shift commenced at the end of the 1990s, when the strategies adopted by the city positioned the renovation and activation of the historic centre of Łódź as one of their main priorities, linking these aims to marketing efforts orbiting around themes of creative classes and culture-led development (Galuszka 2017). This meant significant support for the renovation of postindustrial heritage, the re-densification of the centre and, in some cases, obvious efforts to reintroduce higher socio-economic classes into the area. While initially the process resulted only in the phenomenon of 'pocket gentrification' (Marcińczak 2007), the initiation in 2007 of the New Centre of Łódź mega-project and the large-scale Revitalisation Strategy of 2016 have recently incentivised housing investment in the centre and provided support for the process of rehabilitation of old tenement housing (Galuszka 2017). Consequently, in the 1990s and 2000s, the large housing estates developed in the socialist period were temporarily marginalised in favour of the city's other strategic development goals. Despite the decrease in the number of large-scale projects, this did not mean total stagnation in those areas. In fact, an intensive transformation process took place post-1989 and was steered, to a large degree, by the private sector. According to Ewa Szafrańska (2016), the most important spatial and functional changes in large housing estates included: diversification of housing typologies along with appropriation of public spaces by private entities, the emergence of new commercial spaces and parking lots, the development of places of worship, and enhancement of the quality and aesthetics of public spaces.

A symbolic refocusing of the attention of the city authorities on the large housing estates accompanied the 'Łódź Builds Districts' programme of 2017. In the first run it allocated 30 million PLN (around 7 million Euros) to be invested in line with priorities outlined by the inhabitants of the Łódź districts (Urząd Miasta Łodzi 2018). Lastly, the renewed interest of the central government in social housing resulted in the establishment of 'Mieszkanie +' (Flat + ) programme, which is supposed to deliver 
affordable housing for people unable to obtain flats in a commercial market. While the programme commenced only in 2016 and had delivered only a minimal amount of housing by 2019, its positioning as one of the central initiatives of the government suggests that large housing estates and social housing are again located in the centre of policy debate in Poland.

\section{Olechów-Janów - perceptions, valorisation and the popularity of the district}

While the majority of large housing estates in Łódź are relatively appreciated by their inhabitants (Szafrańska and Mularska-Kucharek 2016), the districts located on the eastern edges of the city stand out as being the most attractive in the city. In spite of the tendency for outward migration of high socio-economic classes from large housing estates in Łódź (Marcińczak et al. 2012), by 2002 Olechów, along with the older neighbouring large housing estates Widzew-Wschod and Widzew-Zachod, ranked in the top 5 of the 25 districts in terms of socio-economic status (Frykowski 2004). A study from 2010 concerning perceptions of quality of life in the city (Mularska-Kucharek and Wiktorowicz, 2012) indicated that the highest scores prevailed in Widzew and Olechów (including Janów) districts. Similarly, research carried out in 2010 revealed that the broader Widzew district (including Olechów-Janów) was considered to be the most attractive destination for people moving out of the eastern part of the city centre (Krzewińska 2010).

The advantages of Olechów-Janów are outlined in the results of a survey from 2012, which investigated perceptions of quality of life in 9 large housing estates in Łódź. As previous research had shown, the district was associated with top levels of contentment among those living there and scored highly in a majority of categories associated with quality of life (such as safety, cleanliness and availability of transport) (Szafrańska and Mularska-Kucharek 2016). These elements clearly contributed to the estate's reputation and corresponded with the main factors identified as motivating the decision of people to move into a specific district (Hedman and Ham 2012). The only major challenges when compared to other districts were the lack of amenities such as parking places, eateries and cultural facilities (Szafrańska 2016). Reflecting this overall positive perception, the district has continued to grow over the last 30 years.

This phenomenon was not unique in the city scale. New dwellings were constructed across whole Łódź in response to the structural housing shortage left after 
the socialist period, (with 22\% growth between 1988 and 2016 and only less than 2\% of dwellings staying empty) (Szafrańska, Couldroy de Lile, and Kazimierczak 2019). However, Olechów-Janów was characterised by truly large-scale investment concentrated in one place and types of structures which consisted almost exclusively of multi-storey housing. Moreover, the district grew in terms of population. In addition to the early period of radical growth stimulated by the initial investment in the mid-1980s, the population of Olechów district also grew between 2003 and 2013, in contrast to other large housing areas from the socialist period whose populations diminished over the same period (Kazimierczak and Szafrańska 2019). For instance the population grew from 3200 in 1988 to 19,600 in 2010 (Szafrańska 2016). Similarly, in comparison to other large housing estates in the city, the district is characterised by a larger proportion of inhabitants of pre-productive and productive ages. Bearing in mind the criteria of population growth, mixed socio-economic status including a relatively high proportion of higher socio-economic groups, and the systematic development of new housing rather than only infill developments, as well as spatial enlargement of the district, OlechówJanów can be considered as 'successful'.

The following part of the article analyses the features of this transformation and reflects on the factors distinguishing the district from other large housing estates in the city. This includes an analysis of housing typologies, public spaces, commercial activities and aesthetics created in the area between 1986 and 2018.

\section{Growth and evolution of the district - housing stock and planning context}

The decision to expand the large housing estates in the eastern part of the city had been legitimised in 1972 with Łódź's Spatial Plan (Bald 2002). However, the document mostly provided a developmental perspective rather than specific guidelines for the development of housing. While in 1979 the city administration issued a decision on the development of the area and conditions for the realisation of Olechow district, those indications were not truly precise. The more bounding legal documentation called Local Spatial Development Plan (Plan Miejscowy) was missing in the area. Consequently, the district's planning process between 1980-1982 was carried out internally by spatial planning departments of the city administration. By the mid-1980s the concept and plan of Olechów-Janów was finalised, and its construction commenced in 1986. Initial 
buildings in the district were ready in September 1987 (Kasicka et al. 2008). By the end of 1994, all of the buildings designed in large panel block technology had been developed by the SM Bawełna, one of the main cooperative housing providers operating during the socialist period. These blocks of flats, in comparison to those constructed in other districts of Łódź over the same period, were characterised by a modest architectural form typical of older estates (figure 1) (Szafrańska 2016). Yet, they also contained large flats of around 55m2 (Kasicka et al. 2008) which, arguably, attracted families of higher socio-economic status right from the outset of the district's development process.

According to the initial plans from 1983, the SM Bawełna was supposed to deliver accommodation for up to 65,000 people (Kasicka et al. 2008). The political transformation after 1989 resulted in changes to the credit system which decreased the investment capacity of the organisation. Consequently, it was required to transfer some of the land it was supposed to develop to private investors and a new social housing corporation which was created in 1995 - the TBS. Around the same time, the new planning system was still in the process of being developed. However, due to a new legislation from 1994, the old Local Spatial Development Plans in the country were no longer considered to be valid and the new ones were not in place yet (Korbel 2015). The absence of those plans continued for years and meant that 'residents, developers and businesses do not have a clear signal on if, when and where developments will occur. Moreover, fragmented developments can make it hard for the local governments to deliver good infrastructure and services in a cost-effective manner' (OECD 2016: 95). Instead the development was steered by administrative planning decisions. This curiously reminded the start of the planning process in the district in 1980s, which at the beginning was developed in similar circumstances. Overall, the lack of fixed planning framework was considered in the last decades to be a menace for the local urban development. However, Olechow-Janow was well positioned to be the site of major development projects even in this 'messy' context. Like in some other cities in the CEE, the pre-definition of big chunks of land for housing development (Ouředníček, Špačková and Pospíšilová 2018), open spaces (Szafrańska 2016) as well as the availability of infrastructure stimulated big-scale development rather then chaotic infill development characteristic in many other districts.

By the end of 1994 all of the construction sites utilising panel technology were completed (figure 1). Up until 2000 the SM Bawełna carried out only a few other 
commercial housing projects in the area, including infill developments next to existing blocks (figure 2).

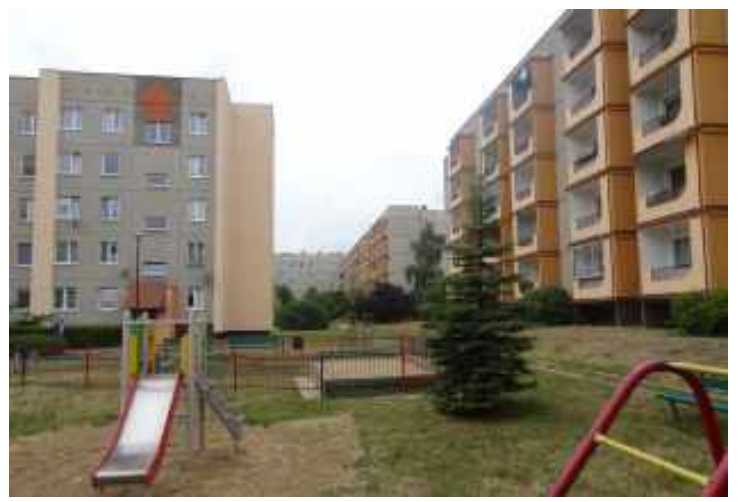

Fig. 1 Blocks of flats from the 1980 s

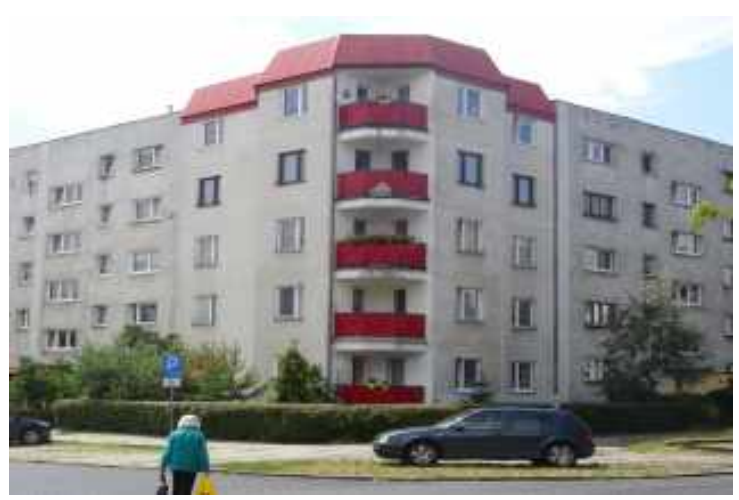

Fig. 2 Infill housing developed in the 1990s

The new buildings varied considerably in terms of design and featured some highly decorative elements, resembling single-family housing units adorned with features reminiscent of aristocratic country houses (figure 3) and included additional amenities like garages and playgrounds. In addition to the investments of the SM Bawełna, between 1995 and 1999 the district also expanded to the south and to the north with new housing constructed mainly by commercial developers. The scale of investment was relatively smaller than in the proceeding and following periods.

Between 2000 and 2005 the area underwent major expansion to the North and East. A large piece of land to the north was utilised by a local social housing corporation - Widzewskie Towarzystwo Budownictwa Spolecznego (TBS-Widzew) (figure 4), which provided social rental housing to people of a specific level of income and with the ability to provide an initial financial contribution towards the costs of construction (TBS, 2018). Expansion to the East by a commercial developer got underway. Though some gated communities were realised, they constituted a minority of the housing delivered in the area.

The period between 2005 and 2011 was also characterised by the delivery of housing for different income groups including social-rental housing (with a possibility of purchasing flats after a specific period of time in some properties) in the Northern and Eastern edges of the district. At the same time, two, large gated communities were introduced in Olechow-Janow and SM Bawełna completed its final investment - a small gated community composed of several buildings. 
A significant shift in the typology of constructed housing can be observed from 2011 onwards, when only gated communities were realized. The newest and ongoing investments include top-end properties, realised on long plots of lands (typical of converted farming plots) on the outskirts of the district (figures 5 and 6). The emergence of gated communities in large suburban housing estates remains untypical in the global context but did also occur in other estates in Łódź (Szafrańska 2012) as well as in the region, for instance in Bucharest, Romania (Marin and Chelcea 2018). However, the scale of this expansion in Olechów-Janów is surprising even in the local context.

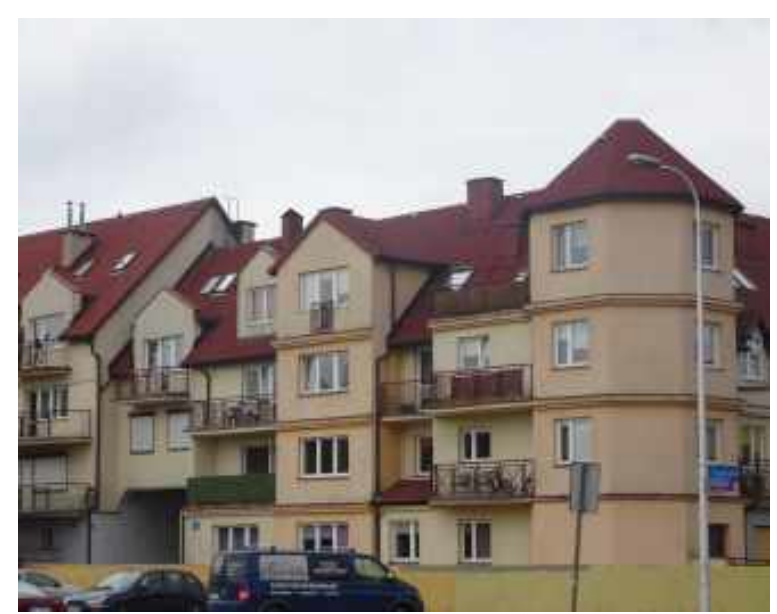

Fig. 3 Early gated community by the SM Bawełna

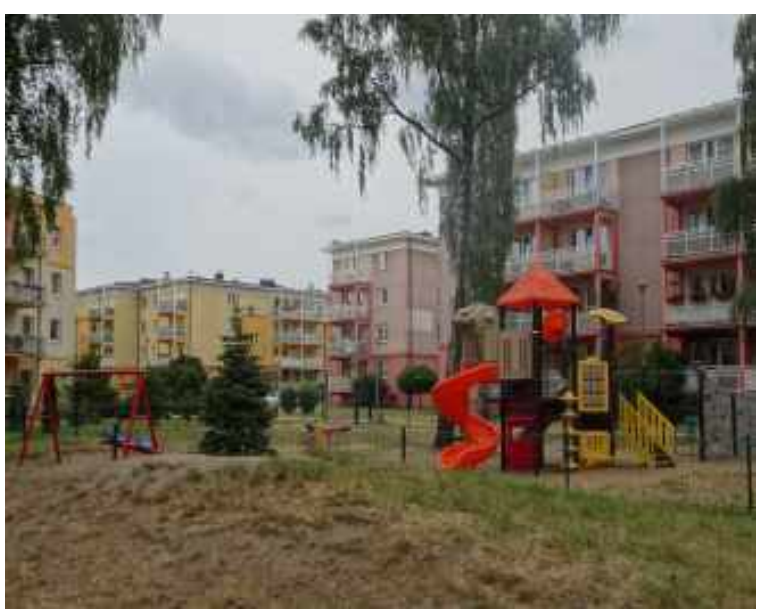

Fig. 4. Rental housing by the TBS-Widzew
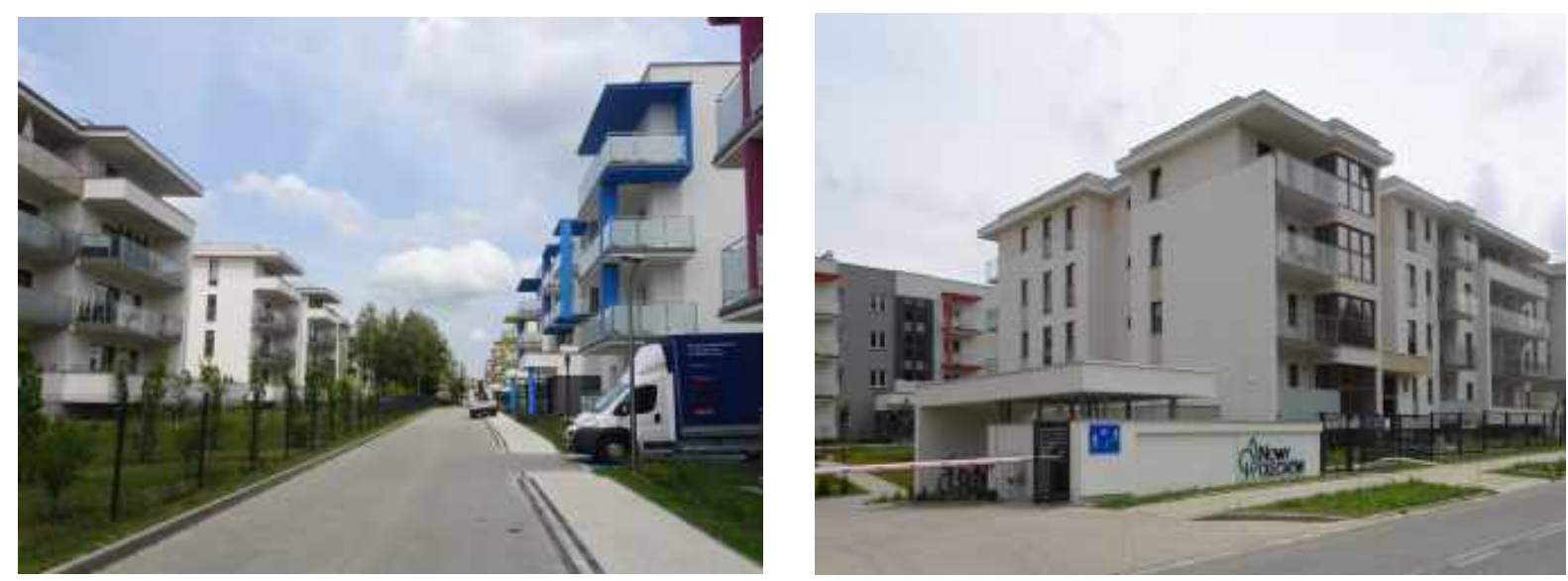

Fig. 5 and 6 Two gated communities in the south-east of the district

Overall, the district has undergone dynamic growth over 32 years, nearly tripling in land area between 1994 and 2018 (figure 7). Until 2011 this involved various types of housing including panel housing, subsidised rental housing, standard commercial 
multi-storey buildings as well as gated communities (see Table 1). The popularity of gated communities in recent years represents a worrying trend of socio-spatial segregation and urban enclaving characteristic of large Polish cities (Szczepański and Ślęzak-Tazbir 2007). However, their development in the locality may have also contributed to a relative increase in the socio-economic status of the inhabitants and supported a further spiral of investment in the area. As in other districts in Łódź (Szafrańska 2013), this investment reached beyond the construction of new housing to include new commercial spaces.

\begin{tabular}{|c|c|c|}
\hline Period & Developer & Type of housing \\
\hline 1987-1989 & -SM Bawełna & Blocks of flats - large panel technology \\
\hline 1989-1994 & $\begin{array}{l}\text {-SM Bawełna, } \\
\text {-Commercial developers }\end{array}$ & $\begin{array}{l}\text { Blocks of flats - large panel technology } \\
\text { Block of flats - commercial developments }\end{array}$ \\
\hline 1995-1999 & $\begin{array}{l}\text {-SM Bawełna (commercial } \\
\text { approach) } \\
\text {-Commercial developers }\end{array}$ & $\begin{array}{l}\text { Gated communities, infill developments } \\
\text { Blocks of flats - commercial developments }\end{array}$ \\
\hline $2000-2005$ & $\begin{array}{l}\text {-TBS-Widzew, } \\
\text {-Commercial developers, SM } \\
\text { Bawełna (commercial } \\
\text { approach) }\end{array}$ & $\begin{array}{l}\text { Social rental housing } \\
\text { Gated communities / Blocks of flats }\end{array}$ \\
\hline $2005-2011$ & $\begin{array}{l}\text {-TBS - Widzew, } \\
\text {-TBS - Zgierz, } \\
\text {-Commercial developers } \\
\text {-SM Bawełna (commercial } \\
\text { approach) }\end{array}$ & $\begin{array}{l}\text { Social rental housing } \\
\text { Gated communities / blocks of flats }\end{array}$ \\
\hline 2011-2015 & -Commercial developers & Gated communities \\
\hline $2015-2018$ & -Commercial developers & Gated communities \\
\hline Ongoing & -Commercial developers & Gated communities \\
\hline
\end{tabular}

Table 1. Typology of housing in Olechów-Janów between 1987 and 2018 
Lastly, post-1994 investment was very diverse in terms of design and contributed to breaking the monotony of the large housing estates typical of the socialist era. Finally, the majority of older housing stock was refurbished with paint and decoration (see figure 1), in a fashion typical across the whole city. 


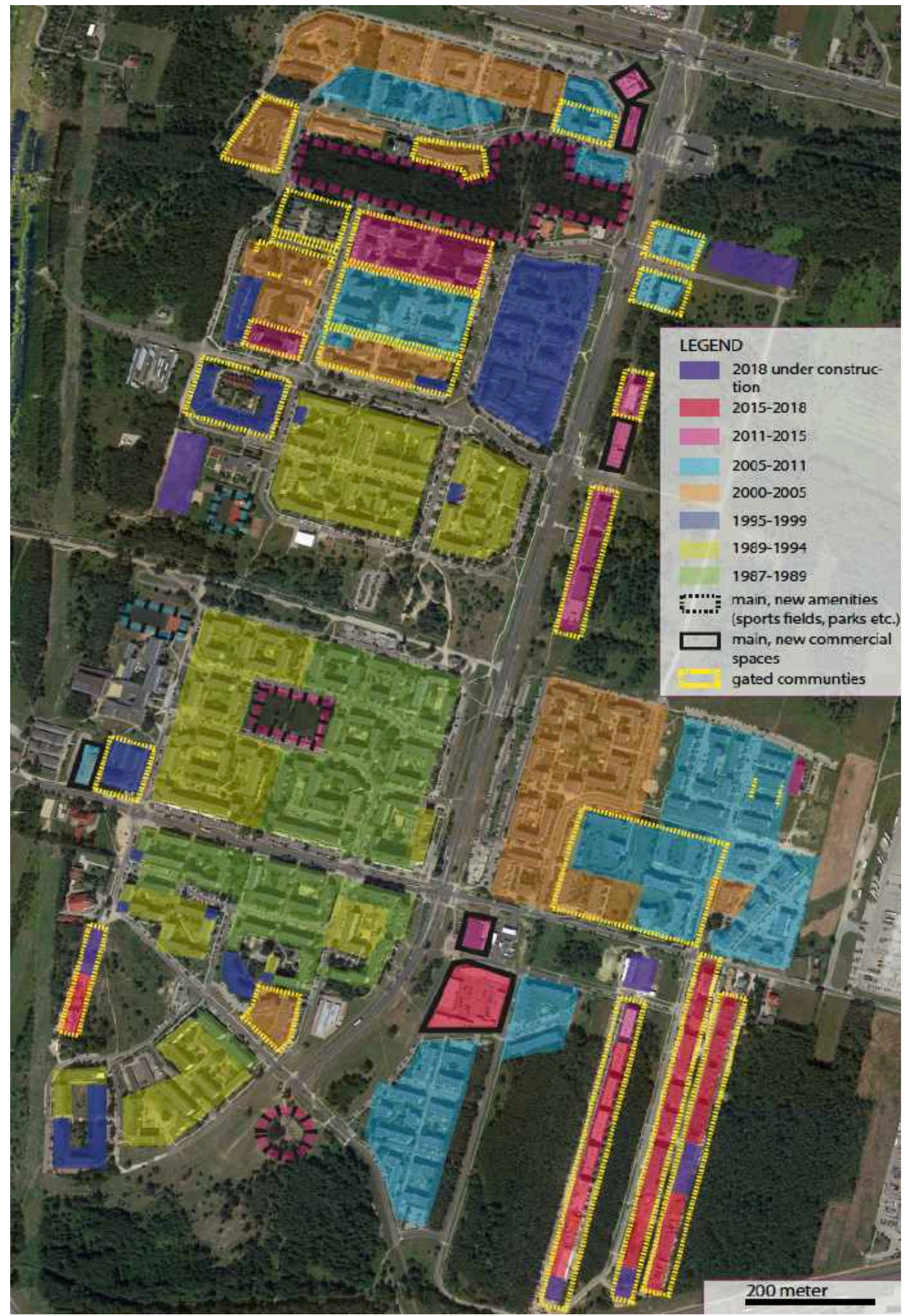

Fig. 7 Transformation of Olechów-Janów between 1987 and 2018. Sources: Kosicka et al. 2008; http://mapa.lodz.pl/ortofotomapy/; http://lodz.retromapy.pl; google.earth.com; author. 


\section{Spatial form, public spaces and recreation amenities}

From the start Olechów-Janów differed in its urban design from the layout of the earlier large housing estates in Łódź, which organised blocks of flats in a linear or parallel manner. The majority of the buildings in Olechów-Janów were organised as blocks, with courtyard-like public spaces between them. With the exception of 6 highrise buildings from the socialist period and one from the 1990s, all of the structures kept to a similar size, up to 5 storeys high. This corresponds with the developments in other CEE cities like Sofia or Belgrade where more human-scale environment was introduced in large housing estates towards the end of socialist period (Hirt 2008).

The majority of the housing projects implemented in the district was also organised as blocks consisting of several buildings with a courtyard. Both the early blocks of flats and the buildings constructed later have playgrounds for children (see figures 1 and 4). The majority of the 'courtyards' include small architecture like benches and some kind of garden and landscaping, most of it professionally maintained (see figure 1) but in some instances self-managed by the inhabitants. Only the most recent gated communities are organised as stand-alone blocks of flat or linear developments and they always include elaborate landscaping and playgrounds for children. Interestingly, levels of maintenance of buildings erected over the same time period can differ a lot. The same also applies to the areas surrounding the buildings. The identifiable common factor in this phenomenon is the affiliation of a group of houses with a specific developer or housing association managing the area. For instance, the green spaces located in a courtyard shared by two different housing associations can have neatly-cut grass on one side and neglected uncut grass on the other side. Similarly, the daubing of buildings by supporters of local football clubs (Gałuszka 2009) tends to be seen only in areas managed by specific housing associations. This does not mean that graffiti happens only there, but rather that in other areas it is removed.

The district has two big avenues that are used by public transport. Between them is a strip of land that was intended for a third, larger, avenue that was never built and is now an unused green field dividing the northern part of the district from the south. Internal streets within the district are characterised by low traffic circulation. For almost three decades the district was served only by buses, which provided a link with the city centre 
in an approximately 30-minute ride. Only in 2015 was a tram service introduced, which is greatly appreciated and much used by the inhabitants (Gazeta Wyborcza 2016).

Bigger public spaces have been introduced in the district only gradually. After 2005 two fully-equipped football pitches were developed thanks to the national level 'Orlik' initiative. Other significant spaces, including larger parks, were introduced only after 2011, but the district itself is surrounded by forests. A major upgrade was the establishment of the Janów Park at a cost of around 180,000 Euros. Interestingly, the funding was secured thanks to a shift of budget from a major campaign aimed at attracting young people to the city (Blewąska 2010). Additionally, organised green areas have been introduced in the district thanks to participatory budgeting. In fact the availability of green spaces emerged as a point of major relevance for the inhabitants of Olechów-Janów during the most recent period of its expansion. Even though overall satisfaction with the provision of greenery in the district is high (Szafrańska 2016), in 2017 and 2018 nearly 1800 people signed a petition against the introduction of new housing in the surrounding forest area (Bujalski 2018). While that particular petition was unsuccessful, citizen pressure did result in the protection of the aforementioned Janów Park as a space to be used solely for recreation and was also successful in overturning the claims of the historical owners of the land (Urzad Miasta Łodzi 2017).

An overall analysis of the transformation of the spatial structure of the district over the last 30 years suggests a gradual development of housing alongside the introduction of a variety of additional amenities such as parks and sports fields (figure 7). However a similar ongoing expansion is perceived by some inhabitants as a threat to the green areas in and around the district.

\section{Commerce, culture and administration - mapping of services in the district}

One of the typical changes occurring across the large housing estates in the postsocialist period is the commercialisation of space and the inclusion of new services and administrative functions within their boundaries (Matlovič et al. 2001). This transformation has taken different pathways across the regions. On the one hand, vacant spaces within the estates have been used for the introduction of new structures including malls, small shops etc. On the other hand, the phenomenon of 'garage capitalism' has occurred, meaning the (often) unauthorised adaptation of existing housing structures for commercial use (Vasilevska et al. 2015). Both trends diversified 
strongly mono-functional areas and became manifestations of the broader transformation of socialist cities.

Bearing in mind the emergence of various typologies of housing often characterised by different design principles, the mapping in Olechów-Janów traces the spatial-functional structure of commercial activities and their interrelation with the overall development of the district. The analysis distinguishes services based on their main function and the location as well as type of structure in which they are located, and also takes into consideration the period in which they emerged. Consequently, the analysis includes only those services which are prominent in the urban space of the district. This excludes services which are not accessible and visible from street level.

Overall, the analysis indicates that there are 208 commercial spaces (including 11 vacant ones) and 21 educational/admin/religious institutions in the district. 197 services are operating and are distributed as follows:

\begin{tabular}{|l|l|l|l|}
\hline Type & North & South & $\begin{array}{l}\text { Olechów- } \\
\text { Janów }\end{array}$ \\
\hline Groceries & 15 & 32 & 47 \\
\hline Specialist shops & 3 & 28 & 31 \\
\hline Beauty, hairdressers, fitness & 11 & 12 & 23 \\
\hline Restaurants/bars/cafes & 6 & 12 & 18 \\
\hline $\begin{array}{l}\text { Services (such as: lawyers, } \\
\text { accountants) }\end{array}$ & 2 & 12 & 14 \\
\hline $\begin{array}{l}\text { Craft shops/car washes } \\
\text { Medical services (other than } \\
\text { dentists/ orthodontics) }\end{array}$ & 5 & 9 & 11 \\
\hline Dentists/orthodontics & 7 & 5 & 10 \\
\hline Pharmacies & 4 & 3 & 10 \\
\hline Press outlet (kiosks) & 3 & 5 & 9 \\
\hline Liquor stores & 1 & 6 & 9 \\
\hline Large supermarkets & 2 & 7 & 8 \\
\hline Gambling & 1 & 2 & 4 \\
\hline ALTOGETHER & $\mathbf{6 2}$ & 2 & 3 \\
\hline Vacant & 4 & 7 & 1197 \\
\hline
\end{tabular}

Table 2. Commercial spaces in the district 


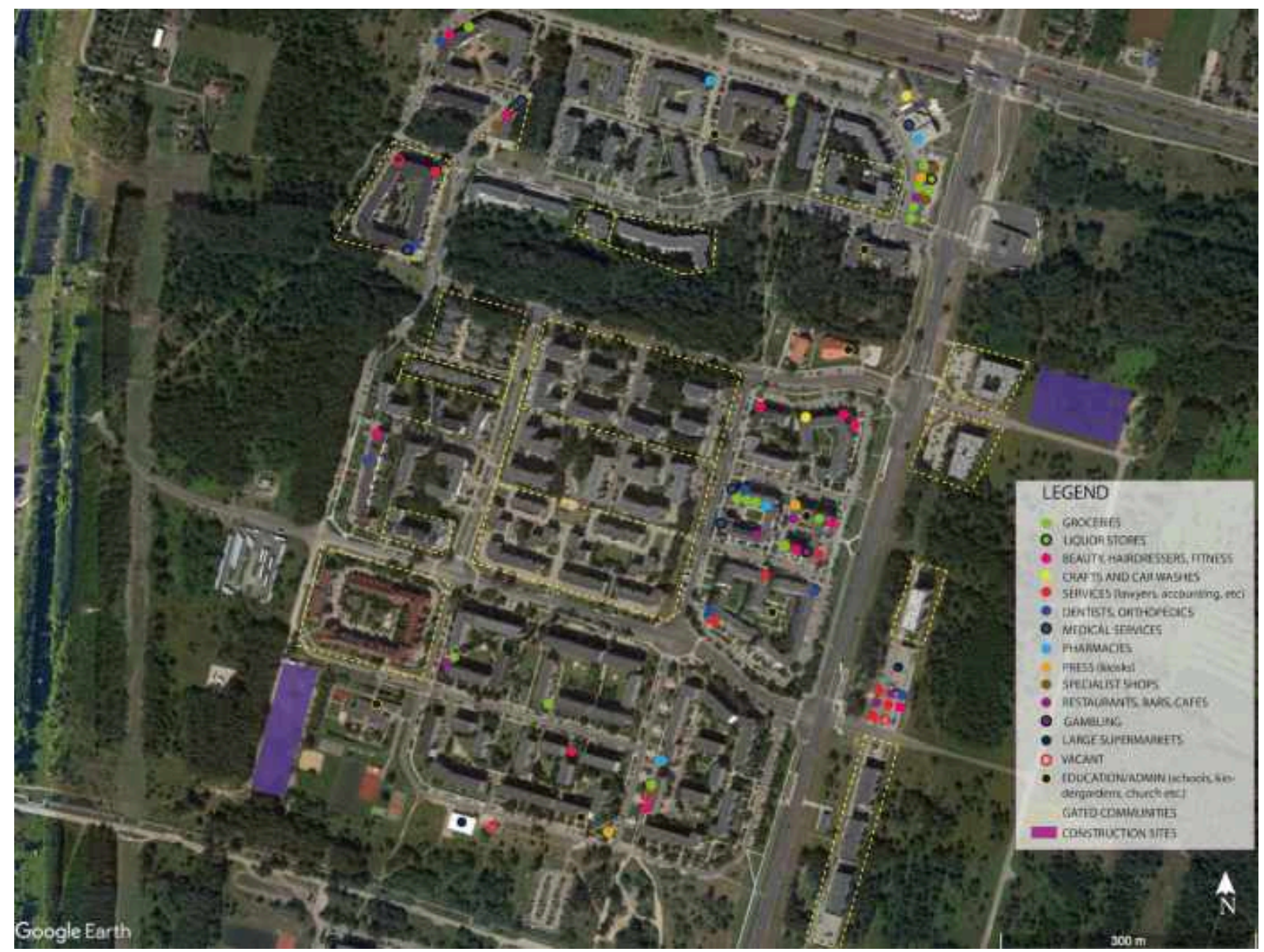

Fig. 8 Commercial activities and services in the north part of the district

Unsurprisingly, the greater proportion of services is located in the southern part of the district, which occupies almost twice as large an area as the northern part. There was a very small number of vacant commercial spaces, adding up to 11 outlets in all. The location of services is very strongly determined by area and building design. In an obvious way the gated communities have prevented commerce from thriving and have resulted in parts of the gated areas being deprived of some service-oriented and administrative functions (particularly in the northern part of Olechów-Janów).

The visible differences in approach of the various developers in the provision of commercial spaces has resulted in a clustering of services in specific sections of the district. In the south the ground floor spaces of a majority of high-rise buildings from the socialist era were devoted to commercial function. The addition over time of stalls located in container type of structures resulted in the creation of busy commercial streets (figure 10). 


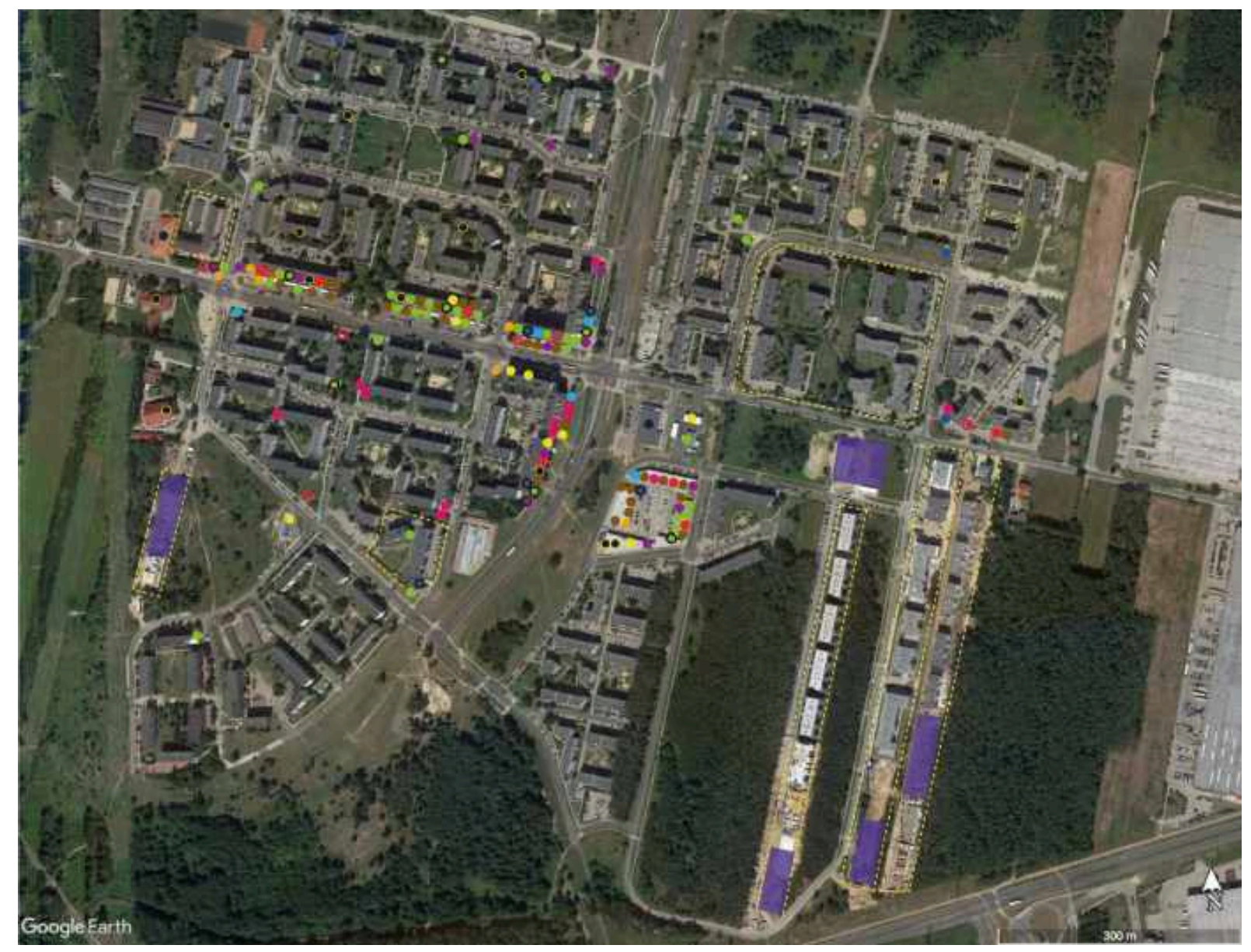

Fig.9 Commercial activities and services in the south part of the district

Similar small extensions, or new pavilions, were devised in the northern part of the district by the residents of flat blocks constructed in the 1990s whose housing provided them with insufficient space. This practice also occurred in the southern part of the district and in other large housing estates (Szafrańska 2016). Between 2011 and 2016 a number of mall-like structures were introduced in Olechów-Janów. These differed from classical large supermarkets through the introduction of diverse functions in one place, including commerce, leisure and entertainment functions. One of these malls in the southern part of the district was positioned centrally between different formats of housing and included 27 different types of shop and fitness and entertainment facility, as well as a kindergarten and a crèche (figure 11).

Overall, the transformation of the district resulted in the incorporation of commercial, educational and public administration functions into the area. Initially most of the spaces were located inside the buildings or emerged as pop-up spaces. Over time, pavilions, supermarkets and mall-like structures were introduced into the district. The transformation of the area and the efforts of the districts' administrators also resulted in 
the eradication of pop-up commercial spaces, with only one pop-up fruit stand encountered during the fieldwork (figure 12). This reflects the vision of orderliness that drove many policy responses in Central and Eastern Europe and became a standard of desired urban environment and, arguably, enhanced perceptions of the prestige of the area.

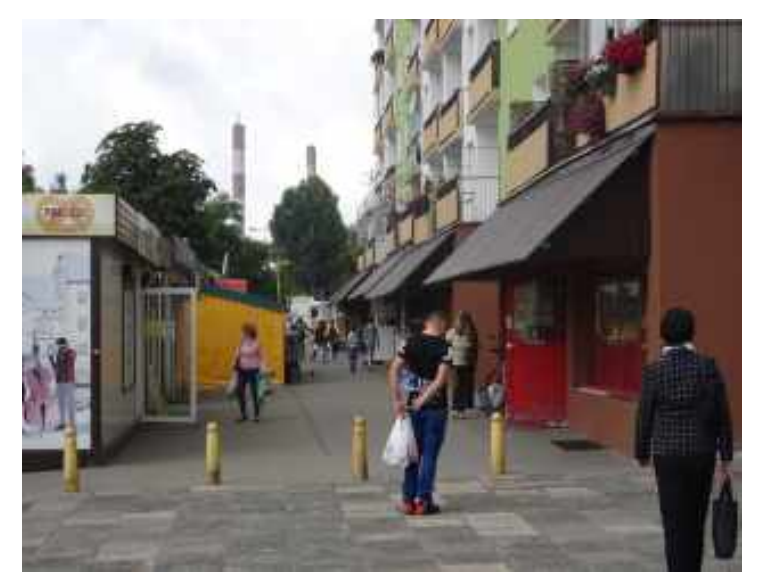

Fig. 10 'Commercial street' in southern part of the district

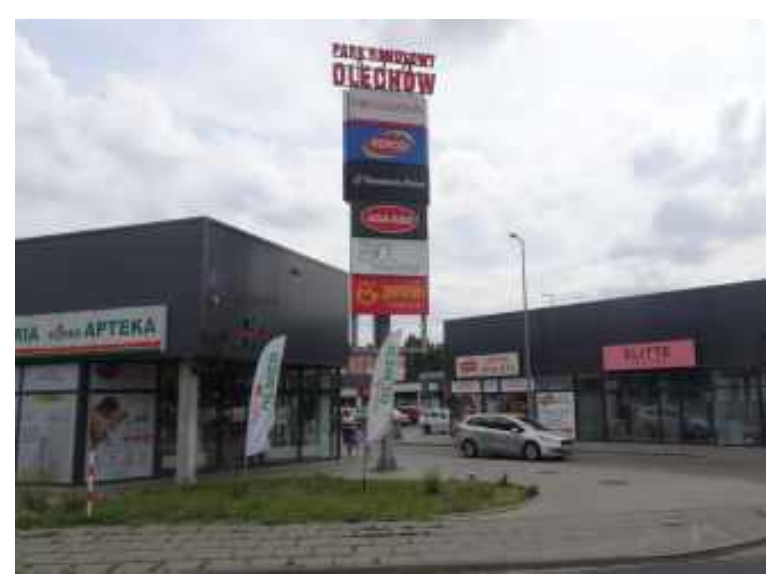

11. New retail centre/mall from 2016

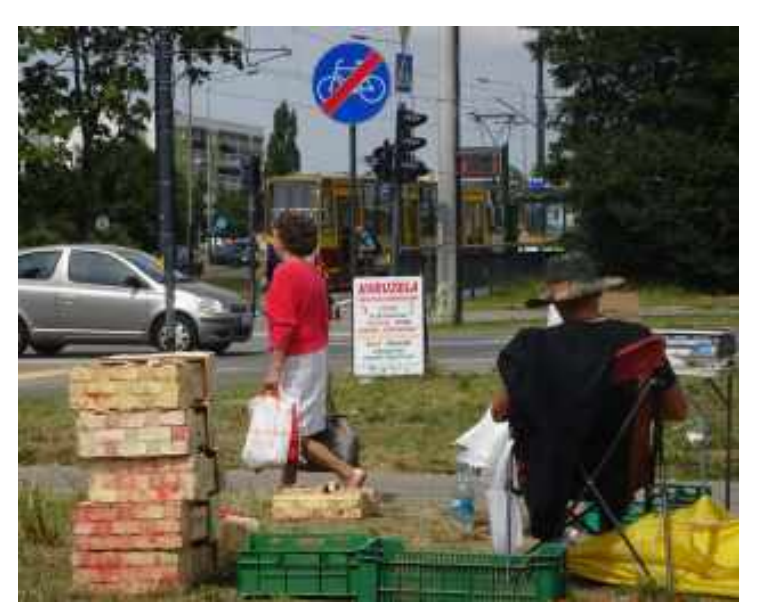

Fig. 12 The only pop-up commercial spot in the district

This conclusion is supported by an analysis of the type of structures in which services are located. Unlike in some older estates in southern Europe (Vasilevska et al. 2015), extensions to spaces are rare. The overwhelming majority of commercial outlets are organised in allocated slots inside residential buildings or legally-constructed pavilions or malls. Only a small fraction of services is located in extensions to the existing buildings or situated in 'kiosk'- type structures. 


\section{Discussion and conclusions}

The research documents the alternative pattern of development of a large housing estate in the European context. It illustrates that this kind of housing typology may be an attractive living location for people from diverse socio-economic backgrounds. In spite of relative similarities to some of the transformation trends in other local estates (such as commercialisation or the emergence of gated communities) Olechów-Janów is the only large housing estate in the city that experienced very large scale, systematic growth after the socialist period. There are several conclusions that can be drawn from this study that are of relevance to policy making and planning in the CEE context.

Firstly, the key component for the development of the district was the availability of land for development and proximity to infrastructure. In the face of legal chaos during the early 1990s, the clear designation of the land for housing construction - a policy inherited from the socialist period - resulted in the creation of an environment conducive to the development of the district by private and public sector-supported enterprises. This process was also facilitated by the peripheral location of OlechówJanów, which allowed its expansion into surrounding greenfield areas. The private sector effectively utilised this opportunity with its participation in the development of the area being crucial for the district's popularity and for the fact that its built area grew by two-thirds.

While the district was originally planned as another major estate constructed solely of large panels, the change of political system in 1989 triggered the diversification of housing output in Olechów-Janów. However, though the private sector steered much of its development, social-rental housing companies were also allowed to investment in the locality. Only in recent years, once land was no longer readily available for large investment, has the new housing output been dominated solely by private companies targeting affluent customers. These new developments, which were built at a smaller scale than previous developments typically on the type of narrow plots characteristic of farmland, suggest that the land was purchased directly from private owner.

This leads to the second lesson from the study - that the public sector can and should shape the housing mix with the involvement of the private sector, but that one of the most effective tools for doing so involves public sector legal or planning control over the urban land. In fact, facing massive privatisation across the CEE, during the last three decades many municipalities have lost control over this type of asset. Current policy 
efforts driven by the central government in Poland, including programmes such as Mieszkanie+, have tried to fill this gap by sourcing cheap land from railway companies and similar entities that are to some degree controlled by the public sector. However, this approach may contradict planning strategies at a local level, promote locations unsuited for such developments, and lead to the concentration of similar socio-economic groups in one location. Consequently, solutions involving long-term land banking facilitated directly by city authorities that mix purely commercial and social-housing districts, as well as the application of a subsidiarity mechanism, may result in more promising outcomes.

Thirdly, the analysis of spatial order and public spaces reveals another way in which Olechów-Janów differs from the other large housing estates in the city. On the one hand, the district is characterised by architecturally diverse forms of building, while on the other hand it maintains continuity in terms of its urban design. Buildings in Olechów-Janów are almost exclusively limited to 5 storeys and organised in block structures, which enables the introduction of semi-public courtyard-like spaces used as playgrounds for children, and green spaces. The main issue in terms of continuity of urban space is related to the barriers introduced by the gated communities.

While the organised public spaces have been gradually introduced with the support of its inhabitants, the district is itself located in the vicinity of green and recreation areas. In spite of the seemingly unattractive peripheral location of OlechówJanów and, until recently, the fact that available public transportation has been limited to buses only, this proximity to green and other recreational spaces has been pointed out by inhabitants as its major advantage. Overall, this suggests that 'suburban life' may emerge as equally attractive as the offerings of the revitalised, central locations of the 'creative' city. In particular, the popularity of very new and expensive gated communities suggests that it is not only the criterion of affordability (Dekker et al. 2011) that is crucial for people to move to these locations. This could suggest to policy makers that the revitalisation of inner cities - hitherto so strongly prioritised in the CEE context (Galuszka 2017) - should not be considered a superior planning priority in comparison to the upgrading of more peripheral districts, particularly given that cumulative investment in one location is known to stimulate the gentrification process also in the CEE context (Kubes \& Kovac 2020).

Fourthly, this study found that significant characteristics of the estate were its maintenance of green spaces and general cleanliness, and that these related to the work 
of the administrators of specific groups of houses or housing cooperatives. Occasional issues of poor maintenance of structures or vandalism are spatially limited to areas where specific housing associations/administrations are in charge of the open spaces and buildings. This suggests that management structures play an extremely important role in the way the district is maintained. Overall in the case of Olechów-Janów this function is well performed by the majority of involved entities. Particularly because there is no visible correlation between the financial capacities of the estates' inhabitants and the level of maintenance of buildings and surrounding areas, a systematic analysis of their management structures is required in order to generate a full understanding of the phenomenon.

Additionally, and not surprisingly, the analysis of the commercial activities in the district reveals the importance of urban design measures in the way commerce is organised. Close to full occupancy of outlets located on the ground floors of buildings, as well as the necessity to supplement them with pavilions and malls, suggests the potential of integrating more commerce into the area and introducing more cultural and entertainment facilities into the district. Additionally, the emergence of mall-like structures in recent years that incorporate entertainment and leisure venues has coincided with the development of large gated communities. This suggests that the influx of affluent inhabitants and the development of this kind of housing supports the diversification of commonly accessible commercial and public spaces but also results in the creation of spatial barriers in the district.

While analysis of the evolution of Olechów-Janów provides a number of lessons and suggests measures that could be applied in regeneration strategies for rundown estates across the continent, the district may itself be faced with the unexpected challenge of enclaving and overconcentration of higher socio-economic groups in parts of the district. The degree to which diversity of housing typologies relates to the actual process of social mixing remains a topic for further studies. The major European agendas like the Leipzig Charter position the creation of diverse neighbourhoods as a key to the creation of social cohesion. However, it is essential to understand whether the spatial proximity of different housing formats and socio-economic groups indeed translates into increased social interactions between inhabitants or the segregation between new and old inhabitants or different social groups is present at a micro level (for instance between specific buildings) (Garrido 2018, Ouředníček, Špačková and Pospíšilová 2018, Marcińczak \& Hess, 2019). Although the spatial morphology of the 
district, its relative walkability and the central positioning of commercial, entertainment and leisure spaces suggests that there is a supportive environment for these interactions, the recent domination of new gated communities puts into question the notion of a 'district as a whole'.

At the same time, Olechów-Janów, stands in sharp contrast to the imaginaries of the decaying large housing estate, haunted by deep social issues and criminality. Rather, with its relatively young population and modern amenities it emerges as a liveable district attracting diverse groups of newcomers. While objective indicators such as the continuous enlargement of the district over the last 30 years, the new amenities, diverse housing forms and good maintenance of spaces, clearly point to the positive pattern in district's development, further studies are required to understand the characteristic of living in a 'new large housing estate'. In this context a thorough qualitative inquiry into the motives of people moving into the district, and into the social networks and social mixing, or lack thereof, emerge as especially relevant.

At the same time the patterns of evolution of the district over the past years suggest a rare process of concentration of higher socio-economic groups in suburban blocks of flats. This raises a key question concerning the further expansion of the district and the maintenance of its relatively diverse socio-economic composition related to its capacity to reintroduce diverse housing products into the area. The largely positive role of the private sector in the development of the district over the last 30 years now emerges as a risk. It is time to ask to what degree, and under which conditions, should public sector-led initiatives such as social rental housing development be used to counterbalance the growth of enclaving in the suburbs and the concentration there of higher socio-economic groups. Essentially paradoxical in character and no doubt 'lighter' in comparison to the problems encountered in a majority of large housing estates in Western Europe, this question emerges as a main issue for maintaining the unique housing mix which emerged from a classical large-panel bloc socialist housing estate in a Central European city. 


\section{References}

Bald K. (2002). Planowanie rozwoju i zagospodarowania przestrzennego miasta w ujeciu historycznym. In S. Liszewski (Ed.), Atlas Miasta Łodzi (Plansza XLII). Łódź: Urząd Miasta Łodzi/Łódzkie Towarzystwo Naukowe.

Blewąska, J. (2010). Park na Janowie zamiast programu "Młodzi w Łodzi"? Gazeta Wyborcza. Retrieved from: http://lodz.wyborcza.pl/lodz/1,35136,7522136,Park_na_Janowie_zamiast_programu_ Mlodzi_w_Lodzi_.html (accessed 10 August, 2018)

Bujalski S. (2018). Miasto nie zablokuje inwestycji na Olechowie. Brzozowy las zostanie wycięty. Gazeta Wyborcza. Retrieved from:

http://lodz.wyborcza.pl/lodz/7,35136,23213142,nie-bedzie-blokady-inwestycji-naolechowie-brzozowy-lasek-do.html (accessed 5 August, 2018)

Chelcea, L., \& Druţă, O. (2016). Zombie socialism and the rise of neoliberalism in postsocialist Central and Eastern Europe. Eurasian Geography and Economics, 57(4-5), 521544 .

Clark, W. A., \& Coulter, R. (2015). Who wants to move? The role of neighbourhood change. Environment and Planning A, 47(12), 2683-2709.

Coudroy de Lille, L. (2015). Housing cooperatives in Poland. The origins of a deadlock. Urban Research \& Practice, 8(1), 17-31.

Czepczyński M. (1999). Rozwój i upadek koncepcji osiedli blokowych. Biuletyn KPZK PAN, z. 190, 49-68.

Dean, J. \& Hastings, A. (2000). Challenging Images: Housing Estates, Stigma and Regeneration. Retrieved from: https://www.jrf.org.uk/report/challenging-imageshousing-estates-stigma-and-regeneration (accessed August 10, 2018)

Dekker, K., De Vos, S., Musterd, S., \& Van Kempen, R. (2011). Residential satisfaction in housing estates in European cities: A multi-level research approach. Housing Studies, 26(04), 479-499.

Dovey, K., Ristic, M., \& Pafka, E. (2017). Mapping as spatial knowledge. In K. Dovey, M. Ristic, \& E. Pafka (Eds.), Mapping urbanities: morphologies, flows, possibilities (pp. 9-24). New York and London: Routledge.

Erőss, Á. (2013). Past and present of large housing estates in Visegrad countries and Armenia. FÖLDRAJZI ÉRTESÍTÓ-HUNGARIAN GEOGRAPHICAL BULLETIN, 62(1), 77-82. 
European Union (EU) (2011) Cities of tomorrow. Challenges, visions, ways forward. Retrieved from:

http://ec.europa.eu/regional_policy/sources/docgener/studies/pdf/citiesoftomorrow/ citiesoftomorrow_final.pdf (accessed 10 July 2017)

Feijten, P., \& Van Ham, M. (2009). Neighbourhood change... reason to leave?. Urban Studies, 46(10), 2103-2122.

Ferenčuhová, S. (2012). Cities and urban research in postsocialist Europe. In T., Edensor \& M. Jayne, Urban Theory beyond the West: A World of Cities (pp. 65-74). London and New York: Routledge.

Frykowski M. (2004). Zróżnicowanie przestrzenne statusu społecznego mieszkańców Łodzi. Studia Regionalne i Lokalne, 15(1), 99-118.

Gałuszka, J. (2009). Przestrzeń manifestacji, czyli jak napisy na murach transformują przestrzeń miejską. Studia Regionalne i Lokalne, 10(35), 110-126.

Galuszka, J. (2017). Examining patterns of policy change in a post-socialist city: the evolution of inner-city regeneration approaches in Łódź, Poland, after 1989. Town Planning Review, 88(6), 639-664.

Garrido, M. (2018). How Interspersion Affects Class Relations. International Journal of Urban and Regional Research, 42(3), 442-460.

Gazeta Wyborcza. (2016). Trasa W-Z. Ilu łodzian jeździ tramwajem na Olechów? http://lodz.wyborcza.pl/lodz/1,35136,19547112,trasa-w-z-ilu-lodzian-lodzianie-jezdzitramwajem-na-olechow.html (accessed August 10, 2018)

Hedman, L., \& van Ham, M., (2012). Understanding neighbourhood effects: selection bias and residential mobility. In M. van Ham, D. Manley, N. Bailey, L. Simpson \& D. Maclennan (Eds.),Neighbourhood Effects Research: New Perspectives (pp 79-99). Springer: Dordrecht.

Hess, D. B., Tammaru, T., \& van Ham, M. (2018). Lessons learned from a pan-European study of large housing estates: origin, trajectories of change and future prospects. In D. B. Hess, T. Tammaru \& M. van Ham (Eds.), Housing estates in Europe: poverty, ethnic segregation and policy challenges (pp. 3-31). Springer: Cham.

Hirt. S. (2008). Landscapes of Postmodernity: Changes in the built fabric of Belgrade and Sofia since the end of socialism. Urban Geography, 29:8, 785-810.

Hirt, S. (2013). Whatever happened to the (post) socialist city?. Cities, 32, 29-38.

Inizan, G., \& de Lille, L. C. (2019). The last of the Soviets' Home: Urban demolition in Moscow. Geographia Polonica, 92(1), 37-56. 
Kamalipour, H., \& Dovey, K. (2017). Incremental urbanisms In K. Dovey, M. Ristic \& E. Pafka (Eds.), Mapping urbanities: morphologies, flows, possibilities (pp. 249-267). New York and London: Routledge.

Kasicka L., Sierakowska E., Gładysiak-Telecka M., Pokorski S. and Gorzkiewicz U. (2008). Robotnicza Spółdzielnia Mieszkaniowa BAWEŁNA. 50-lecie 1958-2008. Łódź: Księży Młyn - Dom Wydawniczy Michał Koliński.

Kazimierczak, J., \& Szafrańska, E. (2019). Demographic and morphological shrinkage of urban neighbourhoods in a post-socialist city: the case of Łódź, Poland. Geografiska Annaler: Series B, Human Geography, 101(2), 138-163.

Kovács, Z., Egedy, T., \& Szabó, B. (2018). Persistence or change: divergent trajectories of large housing estates in Budapest, Hungary. In D. B. Hess, T. Tammaru \& M. van Ham (Eds.), Housing Estates in Europe: Poverty, Ethnic Segregation and Policy Challenges (pp. 191-214). Springer: Cham.

Kovács, Z., \& Herfert, G. (2012). Development pathways of large housing estates in postsocialist cities: An international comparison. Housing Studies, 27(3), 324-342.

Korbel, W. (2015). Skuteczność strategicznego planowania przestrzennego gmin w kontekście istniejącego i projektowanego $\mathrm{w}$ Polsce prawa planowania przestrzennego. ZESZYTY NAUKOWE POLITECHNIKI CZĘSTOCHOWSKIEJ, 20, 36-57.

Kubeš, J., \& Kovács, Z. (2020). The kaleidoscope of gentrification in post-socialist cities. Urban Studies, 0042098019889257.

Krzewińska A. (2010). Opinie łodzian o Nowym Centrum Łodzi. In J. Galuszka (Ed.), Wokół Nowego Centrum Łodzi (pp. 45-80). Łódź: EC1 Łódź - Miasto Kultury.

Lefebvre, A., \& Corpetti, T. (2016). Monitoring the morphological transformation of Beijing old city using remote sensing texture analysis. IEEE Journal of Selected Topics in Applied Earth Observations and Remote Sensing, 10(2), 539-548.

Lux, M., \& Mikeszova, M. (2012). Property restitution and private rental housing in transition: The case of the Czech Republic. Housing Studies, 27(1), 77-96.

Maktav, D., Erbek, F. S., \& Jürgens, C. (2005). Remote sensing of urban areas. International Journal of Remote Sensing, 26(4), 655-659.

Marcińczak, S. (2007). The socio-spatial structure of post-socialist Łódź, Poland. Results of national census 2002. Bulletin of Geography. Socio-economic Series, (8), 65-82.

Marcińczak, S., \& Hess, D. B. (2019). Vertical segregation of apartment building dwellers during late state socialism in Bucharest, Romania. Urban Geography, 1-26. 
Marcińczak, S., \& Sagan, I. (2011). The socio-spatial restructuring of Łódź, Poland. Urban Studies, 48(9), 1789-1809.

Marcińczak, S., Musterd, S., \& Stępniak, M. (2012). Where the grass is greener: social segregation in three major Polish cities at the beginning of the 21st century. European Urban and Regional Studies, 19(4), 383-403.

Masser, I. (2001). Managing our urban future: the role of remote sensing and geographic information systems. Habitat International, 25(4), 503-512.

Marin, V., \& Chelcea, L. (2018). The Many (Still) Functional Housing Estates of Bucharest, Romania: A Viable Housing Provider in Europe's Densest Capital City. In D. B. Hess, T. Tammaru \& M. van Ham (Eds.), Housing estates in Europe: poverty, ethnic segregation and policy challenges (pp. 167-190). Springer: Cham.

Matlovič, R., Ira, V., Sýkora, L., and Szczyrba, Z. (2001). Procesy transformacyjne struktury przestrzennej miast postkomunistycznych (na przykładzie Pragi, Bratysławy, Ołomuńca oraz Preszowa). Miasto postsocjalistyczne-organizacja przestrzeni miejskiej i jej przemiany. Konwersatorium Wiedzy o Mieście , XIV, 9-21.

Mularska-Kucharek, M., \& Wiktorowicz, J. (2012). Jakość życia mieszkańców Łodzi. Wymiar subiektywny. Studia Regionalne i Lokalne, 2(48), 92-117.

OECD (2016). Governance of Land Use in Poland: The case of Łódź. OECD Publishing: Paris, https://dx.doi.org/10.1787/9789264260597-en (accessed March 25, 2020)

Ouředníček, M., Špačková, P., \& Pospíšilová, L. (2018). Long-term development and current socio-spatial differentiation of housing estates in Prague, Czechia. In D. B. Hess, T. Tammaru \& M. van Ham (Eds.), Housing estates in Europe: poverty, ethnic segregation and policy challenges (pp. 339-359). Springer: Cham.

Rykiel Z. (1999). Przemiany struktury społeczno-przestrzennej miasta polskiego a swiadomosc terytorialna jego mieszkanców. Prace Geograficzne, 170, IGiPZ PAN.

Statistical Office in Łódź. (2017). Łódź w liczbach 2017. Retrieved from: http://lodz.stat.gov.pl/publikacje-i-foldery/foldery/lodz-w-liczbach-2017,3,5.html (accessed 15 August 2018).

Statistical Office in Łódź. (2014). Statystyka Łodzi 2014. Retrieved from: http://lodz.stat.gov.pl/publikacje-ifoldery/ roczniki-statystyczne/statystyka-lodzi-2014,4,11.html (accessed 5 December, 2015).

Stanilov, K. (2007). Housing trends in Central and Eastern European cities during and after the period of transition. In K. Stanilov (Ed.), The post-socialist city (pp. 173-190). Springer: Dordrecht. 
Sýkora, L., \& Bouzarovski, S. (2012). Multiple transformations: Conceptualising the postcommunist urban transition. Urban Studies, 49(1), 43-60.

Szafrańska E. (2012). Gentryfikacja wielkich osiedli mieszkaniowaych - nowe zjawisko czy nadużycie terminologiczne? Konwersatorium Wiedzy o Mieście XXV, 153-167.

Szafrańska, E. (2013). Large housing estates in post-socialist Poland as a housing policy challenge. European Spatial Research and Policy, 20(1), 119-129.

Szafrańska, E. (2016). Large housing estates in post-socialist cities: origin, development, changes, perceptions. Łódź: Wydawnictwo Uniwersytetu Łódzkiego.

Szafrańska, E. \& Mularska-Kucharek, M. (2016). Selected Aspects of the Quality of Life of the Inhabitants of Large Housing Estates in Łódź. Socio-Spatial Context. Studia Regionalia, 45, 60-78.

Szafrańska, E., Coudroy de Lille, L., \& Kazimierczak, J. (2019). Urban shrinkage and housing in a post-socialist city: relationship between the demographic evolution and housing development in Łódź, Poland.Journal of Housing and the Built Environment, 34(2), 441-464.

Szczepański, M. S., \& Ślęzak-Tazbir, W. (2007). Between fear and admiration. Social and spatial ghettoes in an old industrial region. Polish Sociological Review, 159(3), 299-320.

Szelenyi I. (1996). Cities under socialism - and after. In G . Andrusz, M Harloe \& I Szelenyi (Eds.), Cities after Socialism. Urban and Regional Change and Conflict in PostSocialist Societies. Oxford: Blackwell Publishers.

Szukalski P. (2012). Sytuacja demograficzna Łodzi. Łódź: Wydawnictwo Biblioteka.

Temelová, J. (2007). Flagship developments and the physical upgrading of the postsocialist inner city: the golden angel project in prague. Geografiska Annaler: Series B, Human Geography, 89(2), 169-181.

Towarzystwo Budownictwa Spolecznego. (2018). Retrieved from: http://www.wtbs.pl/ (accessed, 14 August, 2018).

Turkstra, J. (1998). Urban development and geographical information: Spatial and temporal patterns of urban development and land values using integrated geodata, Villavicencio, Columbia. ITC publication no. 60, International Institute for Aerospace Survey and Earth Sciences. Netherlands: Enschede.

Urząd Miasta Łodzi. (2017). Retrieved from:

https://uml.lodz.pl/aktualnosci/artykul/park-na-janowie-bedzie-chronionyid16489/2017/11/14/ (accessed August 10, 2018). 
Urząd Miasta Łodzi. (2018). Retrieved from: https://uml.lodz.pl/dla-mieszkancow/lodzbuduje-dzielnice/ (accessed August 10, 2018).

Vasilevska, L., Milanovic, D., Nikolic, M., Vranic, P., \& Milojkovic, A. (2015). “Garage capitalism" as a form and process of post-socialist urban changes: Its pace, intensity and structural characteristics. A case study of Nis, Serbia. Habitat International, 48, 149-158.

World Urban Forum IX. (2018). Retrieved from: http://wuf9.org/programme/trainingevents/the-management-of-multi-apartment-high-rise-housing-stock-localizing-sdg-11and-the-nua/ (accessed June 10, 2018). 